\title{
A Cross-Cultural Comparison of Perceptions Regarding Human Trafficking
}

\author{
Adam Tanielian \\ King Faisal University \\ Email: adam.tanielian@gmail.com \\ Sangthong Tanielian \\ Rajabhat Chiang Mai University \\ Email: nook-romain@hotmail.com
}

\begin{abstract}
This study surveyed 135 individuals, of which 68 were native English speakers and 67 were native Thai speakers. Respondents answered questions on issues related to human trafficking, its causes, and potential solutions. Statistical tests showed significant variance in opinions between language and other groups regarding factors associated with trafficking and regarding the potential impacts of the legalization of prostitution. Thai responses reflected collectivist cultural perceptions, while English responses reflected more individualistic views. Males and English speakers were most likely to think legalized prostitution would lead to a reduction in human trafficking while females and Thai speakers were most likely to believe legalized prostitution would increase trafficking. Responses to an open-ended question showed participants felt similarly about potential remedies for human trafficking, including information and awareness campaigns, interactions between civilians and police, increased penalties for offenders, and reduction in macro-environmental variables such as poverty.
\end{abstract}

Keywords: Exploitation, Human Rights, Human Trafficking, Slavery

\section{INTRODUCTION}

Human trafficking is a global criminal phenomenon in which trade routes are historical, growing, and continuously adapting. Victims come from and can be found in any country. Networks of traffickers span the globe, operating within legal transportation and commercial supply channels. Buyers tend to be affluent, but aside from access to capital, they are as diverse as victims and traffickers. Estimates vary on the number of trafficking victims around the world, but none, aside from the traffickers and buyers themselves, would suggest human trafficking is not a serious problem.

Victims of trafficking are subjected to unimaginable conditions, treatment, and exploitation that cause severe physical and psychological trauma. Some die during abduction, transit, transfer, harboring, or after a tertiary buyer takes control for the purposes of sexual exploitation, forced marriage, involuntary labor, organ 
removal or other abuses. Those who are rescued, escape, or otherwise become emancipated face a complicated process of reintegration into social networks that did not or could not support or protect them before their departure. In the worst cases, victims are blamed for their experiences by morally corrupt communities whose law enforcement officials may be facilitating illicit trades for supplemental income.

Human trafficking is one of the most egregious forms of abuse yet compared to other human rights violations (i.e. war crimes, genocide, ethnic cleansing), relatively little is known about human traffickers or their victims. Police and court statistics provide only a crude glimpse at the global market. Nongovernmental organizations (NGOs), intergovernmental organizations like Interpol and offices of the United Nations, and secular government offices report estimates of the number of trafficking victims, but there is no consensus on what an appropriate approximation is. For the years 2012-2014, the United Nations Office on Drugs and Crime [UNODC] reported 63,251 victims in 106 countries. ${ }^{1}$ The United States Department of State's Trafficking in Persons Report reported 100,409 victims in the year 2017, corresponding to 17,880 criminal prosecutions leading to 7,045 convictions. ${ }^{2}$ These numbers are likely only a small fraction of the total number of victims as they represent only cases where police and courts were involved.

Crime occurs in relative secrecy, which makes statistical analysis of criminal economies a complicated and imprecise process. Since human trafficking is a global phenomenon, various cultural, legal, and linguistic factors affect aspects of the trade and its study, from defining terminology to enforcement, adjudication, reporting and beyond.

\section{Research Design and Hypotheses}

This study aims to explore potential cultural and linguistic aspects of perceptions on human trafficking. Analysis of opinion data from distinctly different regions, cultures, linguistic heritage, and legal traditions helps qualify and quantify differences and similarities between two survey groups: native speakers of English and native speakers of Thai.

The study aims to confirm or disconfirm two hypotheses:

H1: Thai and English respondents have significantly different opinions regarding aspects of human trafficking.

1 UNODC (United Nations Office on Drugs and Crime), Global Report on Trafficking in Persons, (Vienna: UNODC, 2016) online: UNODC <https://www.unodc.org/documents/dataand-analysis/glotip/2016_Global_Report_on_Trafficking_in_Persons.pdP

2 United States Department of State, Trafficking in Persons Report 2018, (Washington DC: Department of State, 2018) online: 〈https://www.state.gov/documents/organization/282798.pdf> 
H2: English language respondents believe human trafficking is likely to decrease if prostitution is legalized whereas Thai respondents do not believe legalized prostitution would decrease human trafficking.

The study also aims to answer the following questions:

Q1: To what extent, if any, do opinions vary between groups separated by survey language, sex, age, education, and income.

Q2: Why are responses different between groups, or why are responses not different?

Q3: How can the data help stakeholders improve the situation regarding human trafficking?

In the following section, a review of literature provides secondary quantitative and qualitative data. Then, a survey provides primary quantitative data for analysis and interpretation. The discussion section reflects on findings and ties together theory found in literature to form potential courses of future action. Conclusions suggest that we are only in the beginning stages of a thorough remedy for the scourge of the modern-day slave trade which is human trafficking. Most importantly, communication and cooperation among and between police agencies and civilians are paramount in making progress on the overarching goal of abolition of the modern-day slave trade, and thus human trafficking.

\section{Legal Background and Prior Research}

Starting in the late 19th century, nations began condemning slavery and trafficking for the purposes of slavery. Jus cogens, or peremptory norms of international law, emerged just prior to the consensus that slavery violated fundamental rights and freedoms. ${ }^{3}$ Shortly after that, the League of Nations Slavery Convention ${ }^{4}$ set out to abolish slavery and the slave trade. As human rights gained acceptance as part of customary international law, the UN General Assembly's Universal Declaration of Human Rights ${ }^{5}$ [UDHR] recognized freedom from slavery or servitude as a fundamental human right. Nearly three-quarters of a century after the Slavery Convention and more than half a century after the UDHR, states adopted the United Nations Convention against Transnational Organized Crime ${ }^{6}$ and its

3 Stephan Kirchner \& Vanessa Frese, "Slavery under the European Convention on Human Rights and the Jus Cogens Prohibition of Human Trafficking” (2015) 27:1 Denning L J 130_ 145, online: <http://www.ubplj.org/index.php/dlj/article/view/1105/1018>

4 League of Nations, Convention to Suppress the Slave Trade and Slavery, 1926, 60 LNTS 253, art 4, online: 〈https://www.refworld.org/docid/3ae6b36fb.html>

5 UN General Assembly, Universal Declaration of Human Rights, 1948, 217 A(III), online: <https://www.refworld.org/docid/3ae6b3712c.html>

6 UN General Assembly, United Nations Convention against Transnational Organized Crime, 2000, A/RES/55/25, online: < https://www.refworld.org/docid/3b00f55b0.html> 
Protocol to Prevent, Suppress and Punish Trafficking in Persons, Especially Women and Children. ${ }^{7}$ The Protocol defines "trafficking in persons" as,

"the recruitment, transportation, transfer, harboring or receipt of persons, by means of the threat or use of force or other forms of coercion, of abduction, of fraud, of deception, of the abuse of power or of a position of vulnerability or of the giving or receiving of payments or benefits to achieve the consent of a person having control over another person, for the purpose of exploitation. Exploitation shall include, at a minimum, the exploitation of the prostitution of others or other forms of sexual exploitation, forced labor or services, slavery or practices similar to slavery, servitude or the removal of organs."

$\mathrm{UNODC}^{8}$ identified four forms of trafficking: forced labor, prostitution, organ removal, and other forms of exploitation. The "other" category includes all forms of trafficking not specifically mentioned in the UN Trafficking in Persons Protocol but identified by government offices and reported to the UNODC; this category may include begging, commission of crimes such as drug trafficking, forced marriage, or adoption. While the terms "human trafficking" and "slavery" are legally distinct, the definition from the Protocol creates an inextricable link in virtually every case of slavery. Prohibition of human trafficking is ipso facto a jus cogens norm. ${ }^{9}$ Because slavery is prohibited by customary international law, states are obliged to prohibit the practice, regardless of whether the state is member to a treaty regarding its prohibition. ${ }^{10}$ As such, all states are duty bound to prohibit human trafficking as defined by the UN Protocol.

Despite immense effort to thwart the slavery and human trafficking menace, the trades persist. The International Labor Office (ILO) ${ }^{11}$ estimated that in the year 2016, as many as 40 million people were victims of slavery, including 15 million in forced marriage. If ILO's estimate is accurate, each of those 40 million victims of slavery would have been victims of trafficking at some point in their lives. The main motivator for offenders appears to be money. Trafficking for the

7 UN General Assembly, Protocol to Prevent, Suppress and Punish Trafficking in Persons, Especially Women and Children, Supplementing the United Nations Convention against Transnational Organized Crime, 2000, art 3(a), online: <https://www.refworld.org/docid/4720706c0.html>

8 UNODC, supra note 1.

9 Cornell Legal Information Institute, "Jus Cogens", online: <https://www.law.cornell.edu/wex/jus_cogens>

10 Maria Perez Solla, "Slavery and Human Trafficking: International Law and the Role of the World Bank", SP Discussion Paper 0904, 2009, online: <https://siteresources.worldbank.org/SOCIALPROTECTION/Resources/SP-Discussionpapers/Labor-Market-DP/0904.pdf>

11 ILO, "Global Estimates of Modern Slavery: Forced Labor and Forced Marriage" (Geneva, Switzerland: International Labor Office, 2017), online: <https://www.ilo.org/global/publications/books/WCMS_575479/lang-en/index.htm> 
purposes of slavery is a multibillion-dollar industry. The United Nations Office on Drugs and Crime (UNODC) ${ }^{12}$ estimated traffickers earn some $\$ 32$ billion annually. People who force victims into various forms of labor earn an additional $\$ 150$ billion each year, according to ILO. ${ }^{13}$

According to a UNODC ${ }^{14}$ study which compared statistics from nearly every country, females accounted for 71 percent of all victims in the year $2014 ; 20$ percent of them were under age 18. Between 2004 and 2014, the male share of victims increased in each of the five UNODC surveys. UNODC estimated children account for more than one-quarter of all victims, and that girls become victims at more than twice the rate of boys. In 71 countries, UNODC found all but a few sex trafficking victims are female; they earn criminals who exploit them profits of about $\$ 100$ billion annually according to $\mathrm{ILO}^{15}$, which is twice the profit from forced labor, whose victims are roughly two-thirds male. The profit margins on sex trafficking victims, and thus females, are several times greater than margins of their male laborer counterparts.

$\mathrm{UNODC}^{16}$ found victim profiles varied from one region to another though some trends are apparent. Children are more likely to become victims in countries that have an abundance of children. UNODC cited "cultural practices" and access to education as demand drivers of child trafficking. Another factor UNODC cited was institutional strength, or whether a state has sufficient legislation and power to enforce. UNODC found improving legislation among 179 countries between 2003 and 2016, by which time 158 countries or 88 percent had implemented statutes covering most or all forms of trafficking. The number of countries meeting legislative standards experienced sustained growth, from just 33 in the year 2003 to 149 of 179 countries in 2014 , but UNODC ${ }^{17}$ discovered countries that adopted laws after 2003 prosecuted far fewer cases than those who adopted laws before 2003. While more countries have signed treaties and implemented laws, prosecutions are rare in most countries, and traffickers have found a very profitable growth market.

Human trafficking persists because of opportunity in the political economy; that is, a complex combination of political and economic factors provides opportunity for traffickers to exploit people. Victims flow in all cardinal directions, but flows are generally out of poverty and into relative wealth; from countries with

12 UNODC, "Human Trafficking: Organized Crime and the Multibillion Dollar Sale of People", 2012, online: <http://www.unodc.org/unodc/en/frontpage/2012/July/human-trafficking_organized-crime-and-the-multibillion-dollar-sale-of-people.html>

13 ILO, "Profits and Poverty: The Economics of Forced Labor", (Geneva, Switzerland: International Labor Organization, 2014), online: <https:/www.ilo.org/wcmsp5/groups/public/ed_norm/-declaration/documents/publication/wcms_243391.pd†

14 UNODC, supra note 1.

15 ILO, supra note 13.

16 UNODC, supra note 1.

17 Ibid, note 1. 
lower human development and income per capita and to countries with higher standards of living. ${ }^{18}$ Reports separated victims by regions that were not drawn purely on ethnic and cultural lines, but regions also tended to reflect distinct ethnography as compared to other regions (i.e., Eastern/Western Europe, Middle East, North Africa, Sub-Saharan Africa, East Asia \& Pacific, South/Central Asia, North American, Latin America). Studies suggested cultural and subcultural views influence how much people tolerated, rationalized, ignored, or reacted to human trafficking. ${ }^{19}$ In summary, different regions are populated by different cultures and groups who are likely to think, feel, and behave differently regarding human trafficking perpetrators, victims, laws, and economies. ${ }^{20}$ This study was designed considering the apparent relationship between human trafficking and cultural, ethnic, national, linguistic, and other social identities.

\section{METHODOLOGY}

A questionnaire survey was deployed to quantify perceptions regarding human trafficking and related topics. To answer research questions and confirm or disconfirm hypotheses, the survey was translated into English and Thai and electronically distributed to speakers of each language.

\section{Participants}

Participants included 68 native speakers of English and 67 native speakers of Thai, all of whom were recruited by researchers via Facebook. Participants were informed of the purpose of the study, that participation was voluntary, and that their identities would remain confidential throughout the research and reporting processes. All participants in both surveys were 20 years of age or older. Aside from confidentiality, there were no outstanding ethical matters to consider. No institutional review board approval was required for this research.

18 UNODC, supra note 1; United States Department of State, supra note 2.

19 Jill Robinson, "Public perceptions of human trafficking in Moldova" (2011) 20:3 Psychological Intervention, 269-279; Stephanie Mace, "Child trafficking: A case study of the perceptions of child welfare professionals in Colorado", (Fort Collins, CO, USA: Colorado State University School of Education, 2013), online: <https://mountainscholar.org/bitstream/handle/10217/78834/Mace_colostate_0053A_11615.pdf?s equence $=1 \&$ isAllowed $=\mathrm{y}>$

20 Kiril Sharapov, "Understanding public knowledge and attitudes towards trafficking in human beings", Research Paper: Part 1, (Budapest, Hungary: Center for Policy Studies, Central European University, 2014), online: <http://astradainternational.org//sidocs/3119-Publicknowledge-and-attitudes-towards-thb-2014.pdf>; Melissa Withers, "Pimp Culture Glorification and Sex Trafficking”, online (2017) Psych Today <https://www.psychologytoday.com/us/blog/modern-day-slavery/201704/pimp-cultureglorification-and-sex-trafficking> 


\section{Instruments}

A 10-question survey assessed attitudes regarding human trafficking among native speakers of English and Thai. Both English and Thai surveys were constructed and delivered via SurveyMonkey. Five questions on the surveys asked for demographic data regarding geographical origin, gender, age, highest level of education, and income. One question asked respondents to quantify the threat level that human trafficking poses to their community, on an integer scale of 0 to 100. One question asked participants to quantify the level of association, on a 5point Likert scale, between human trafficking and ten factors mentioned in literature (i.e. statelessness, poverty, child abuse, lack of education, religion, community morals, bad parenting, prostitution, drugs and alcohol, war and violent conflict). One question asked respondents if the threat that human trafficking poses would increase, decrease, or stay the same if prostitution were legalized. One question asked respondents to rank the four most common purposes human trafficking given choices of labor, prostitution, household servant, and organ harvesting. Finally, one open-ended question asked participants about how people can prevent human trafficking.

*See Appendix for survey

\section{Sampling and Analysis}

In January 2018, researchers began collecting a convenience sample by distributing the SurveyMonkey instruments via Facebook. Several solicitations for participants were made via researchers' personal Facebook feeds until the final response was collected in May 2018. The sample size was 135 totals, with 68 in the English sample and 67 in the Thai sample.

The surveys were translated into two languages and distributed to samples of native speakers of each language so that the population size can be estimated as the population of native English and native Thai speakers, but the survey is intended to apply to a broader population. The sample size may appear small given the large population size, however, the sample is sufficient under the assumption that response distribution is low; that is, very few people deviate from the norm on questions of human trafficking (i.e. people are unanimous in their disapproval of the trade). Sample size was calculated using the following formula. ${ }^{21}$

21 Robert Krejcie \& Daryle Morgan, "Determining Sample Size for Research Activities" (1970) 30 Ed \& Psych Measure 607-610, online: https:/home.kku.ac.th/sompong/guest_speaker/KrejcieandMorgan_article.pdf>; $\quad$ National Business Research Institute, "Sample Size Calculator" (2018), online: <https://www.nbrii.com/our-process/sample-size-calculator/> 


$$
s=\frac{X^{2} N P(1-P)}{d^{2}(N-1)+X^{2} P(1-P)}
$$

$S=$ required sample size

$X^{2}=$ chi-square value for 1 degree of freedom at 95 percent confidence level

$N=$ population size

$P=$ population proportion, estimated at 10 percent

$d=$ degree of accuracy, or margin of error at 0.05

Researchers took note of the limited or logistical growth of the graph of the formula, which yielded a sample size of 130 for a population of 2,000; that sample size grew to 138 for a population of 20,000 and 139 for all populations above 65,000. Researchers felt 135 responses were adequate considering potential interference of factors such as culture, religion, and language within the context of very large populations. For the purposes of exploratory and preliminary confirmatory study, the relatively small sample size was innocuous to validity.

Survey data were translated into Microsoft Excel 2016 and SPSS v23 for representation and analysis. Demographic data aided researchers' understanding of the composition of participants by age, sex, income group, and education. Excel tables helped researchers represent descriptive statistics (i.e., means, frequencies, standard deviation) using tables, line, and bar graphs. SPSS helped calculate complex parametric and non-parametric tests such as one-way and twoway ANOVA, Chi-Square, Kruskall-Wallis, Shapiro-Wilk, and Levene statistics.

\section{RESULTS}

Data were approximately normally distributed as assessed by Q-Q plots; however, Shapiro-Wilk tests showed the data violated the normality assumption with $\mathrm{p}$ scores lower than 0.05 . Data also violated the homogeneity of variance assumption as assessed by Levene's statistic ( $p>0.05)$. Despite these violations, ANOVA was still considered an appropriate test as ANOVA is considered a robust test that tolerates such violations with small effect on Type 1 errors. ${ }^{22}$ To ensure the validity of results, researchers conducted Welch and Kruskal-Wallis tests in response to the violations.

\section{Demographic Data}

Among the 68 participants of the English survey, 32 were male and 36 were female. There were 57 respondents from 22 states across the USA. Among the 11 international respondents on the English survey, there were 2 from Japan, 2 from

22 Lund Research, "One-way ANOVA" (2018), online: <https://statistics.laerd.com/statisticalguides/one-way-anova-statistical-guide-3.php> 
Thailand, 2 from Canada, 2 from Ireland, and 3 from the United Kingdom. All 67 participants in the Thai language survey were from Thailand. Responses were mainly from northern provinces of Chiang Mai and Maehongson, and the capital city area in and around Bangkok. In the Thai group, there were 48 females and 19 males.

Table 1: Survey participants by gender and language.

\begin{tabular}{|l|l|l|l|}
\hline & ENG & TH & TOT \\
\hline Male & 32 & 19 & 51 \\
Female & 36 & 48 & 84 \\
\hline Total & 68 & 67 & 135 \\
\hline
\end{tabular}

Roughly 70 percent of Thai respondents and 46 percent of English respondents were between the ages of 30 and 39. English survey respondents reported a broader range of ages. Figure 1 shows age distributions.

Figure 1: Number of participants by age group and language.

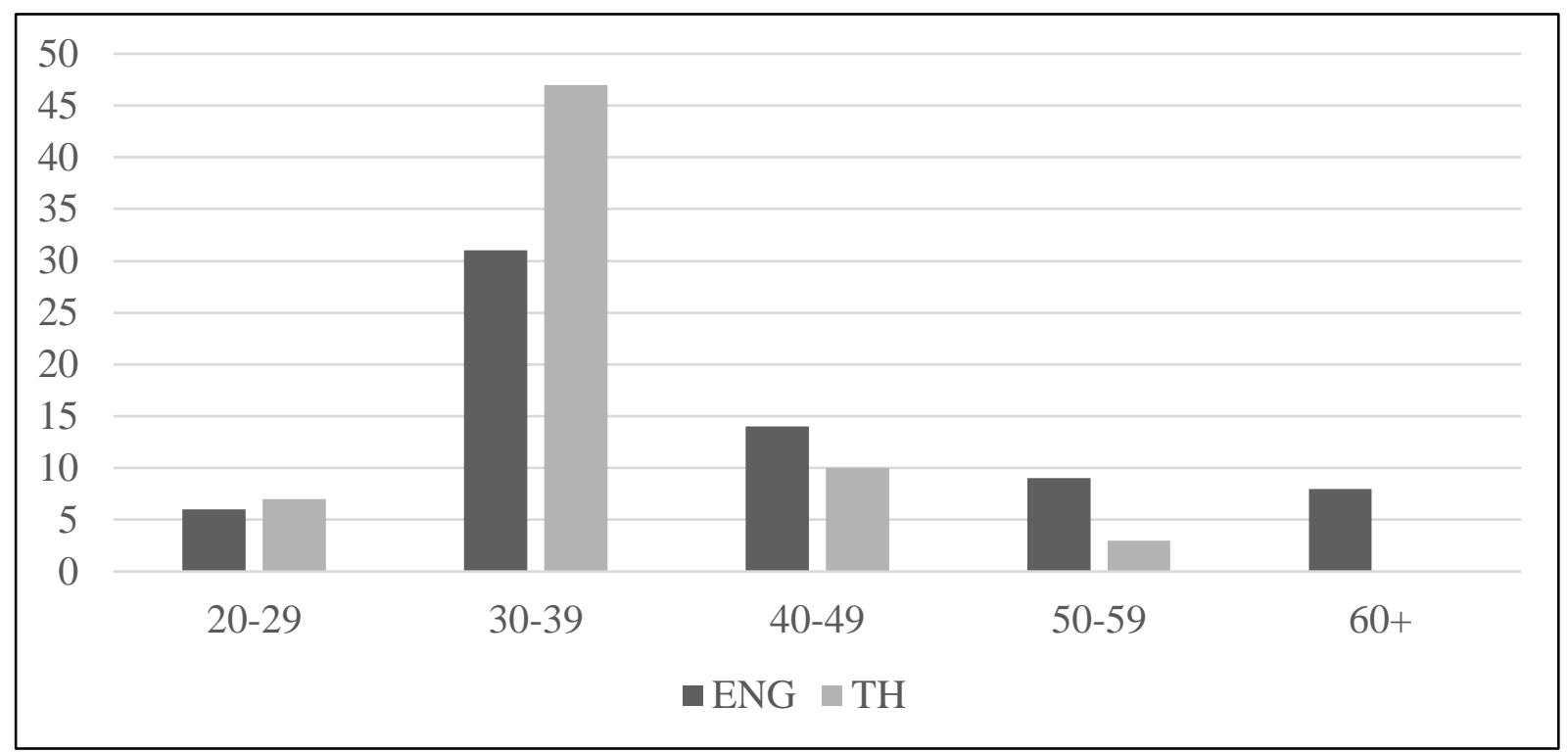

All respondents in the English survey had at least some tertiary education; about 49 percent had a bachelor's degree, and 44 percent had a graduate degree. Thai-language respondents reported slightly lower education overall. English respondents were more likely to have earned a graduate degree, whereas Thai respondents earned more bachelor's degrees. Figure 2 shows a comparison of education distributions. 
Figure 2: Number of participants by highest level of education and language.

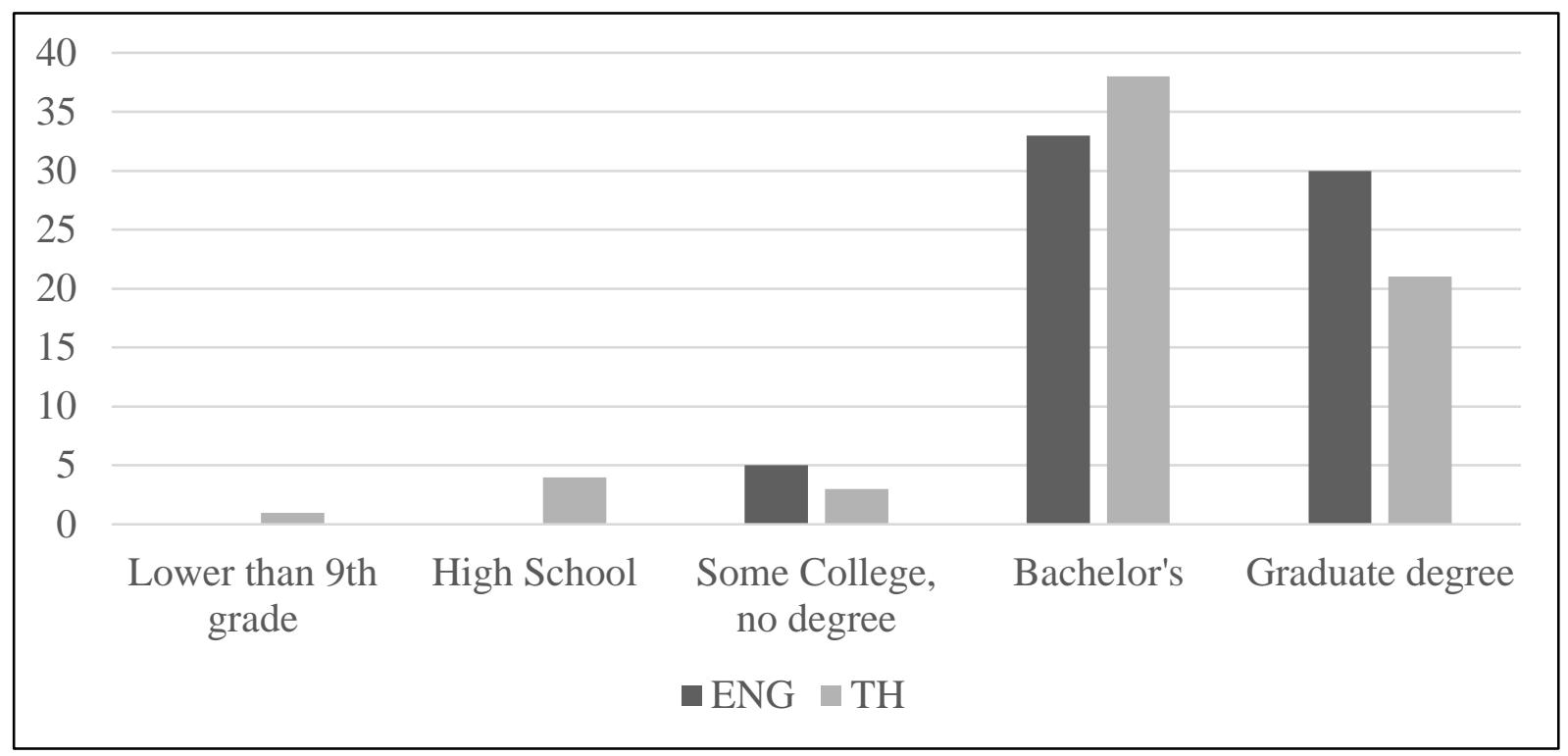

Distribution of incomes in the Thai group resembled a slightly skewed normal curve with roughly 62 percent of respondents earning between 15,001 and 50,000 Thai Baht (THB) per month, or approximately 5,450-18,200 USD per year at 33THB/USD. Figure 3 shows income distribution of Thai participants by income group.

Figure 3: Number of Thai survey participants separated by income group (Baht per month).

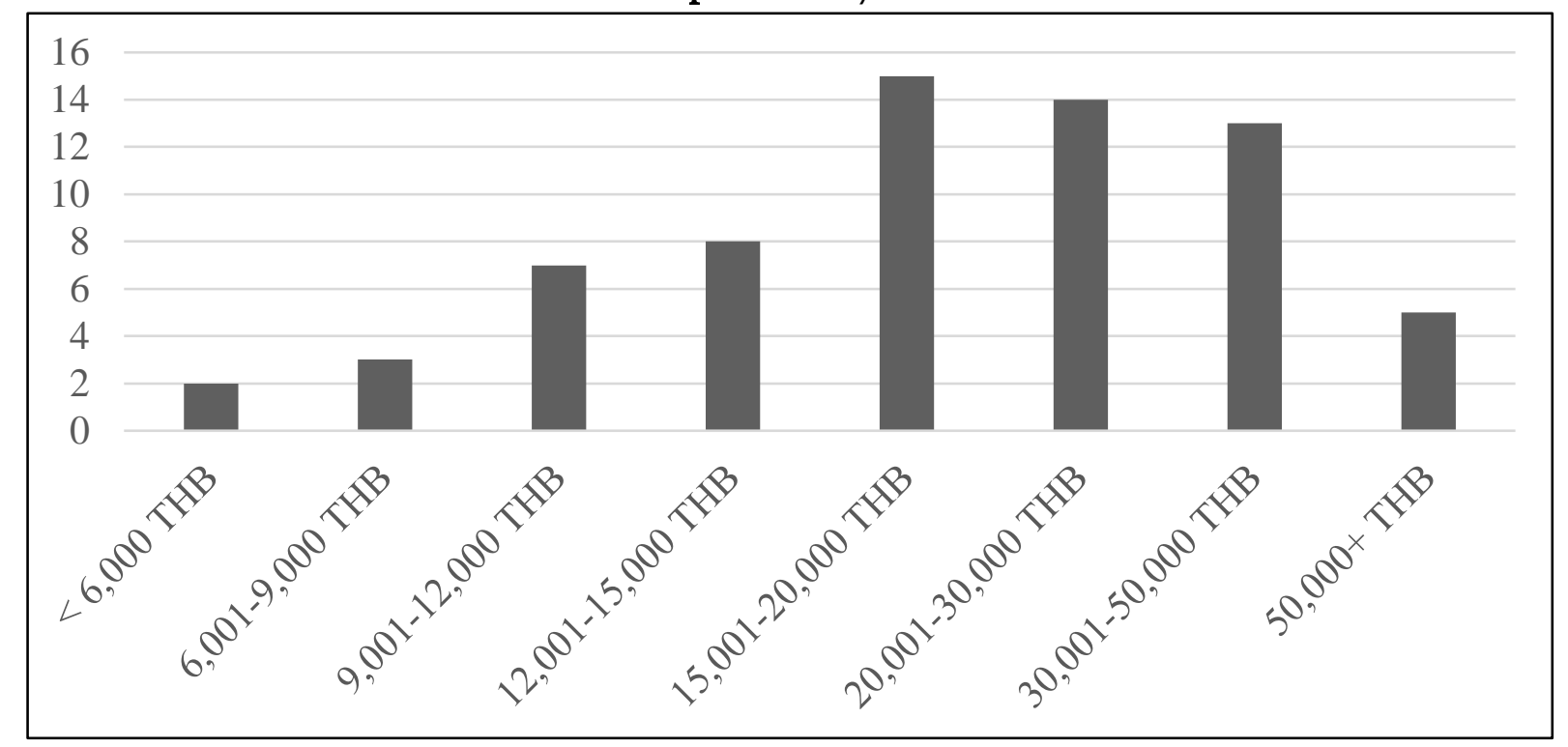


Nearly all Thai respondents had incomes corresponding to the lowest level in the English survey. In the English group, approximately 63 percent of respondents reported annual household income in two categories: 30,000-45,000 USD and above 80,000 USD. Figure 4 shows distribution of English respondents by income group.

Figure 4: Number of English respondents by household income group (USD per year)

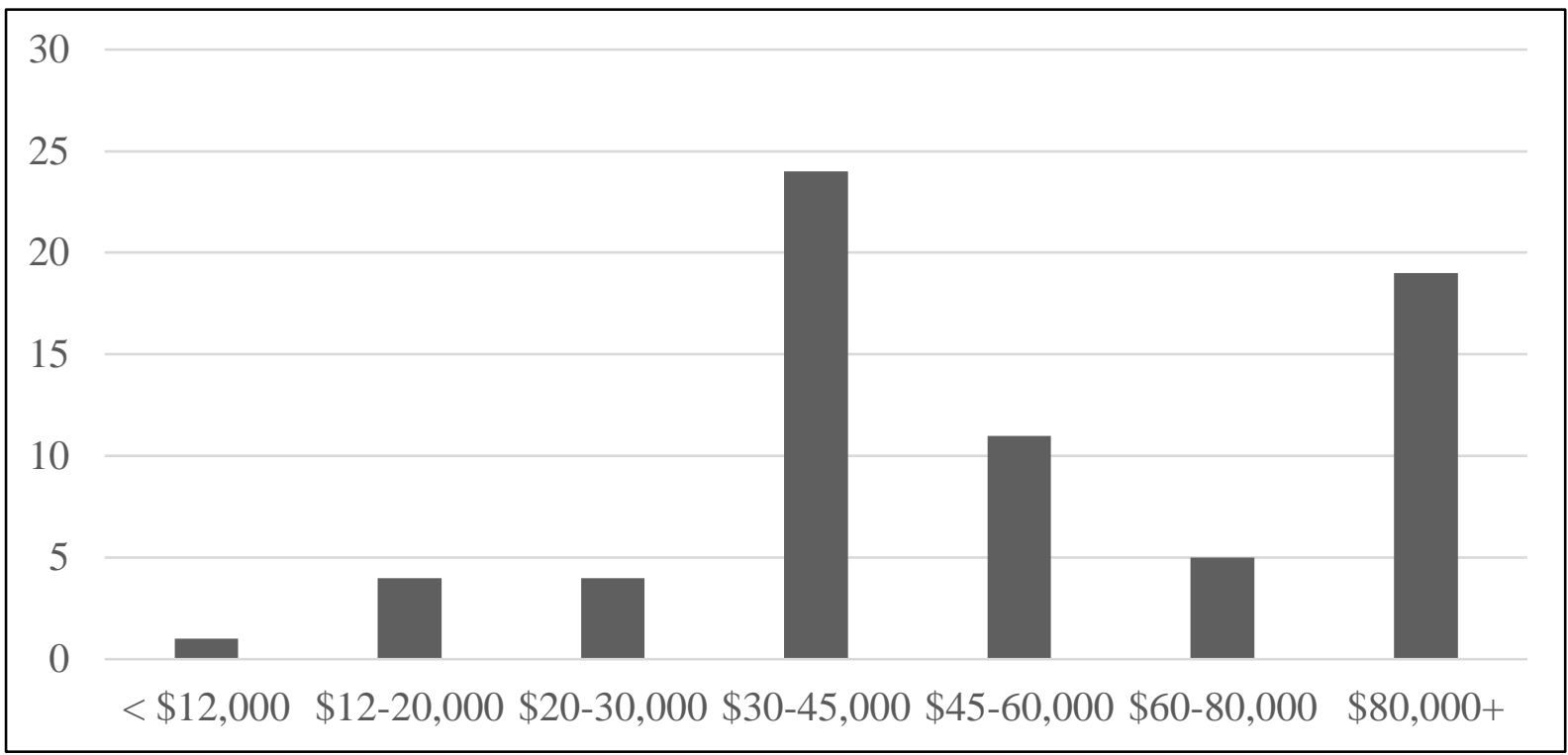

Income disparity between Thai and English groups is partially explained by survey language requesting "household income" for English respondents and "income" for Thai respondents. Household income was thought to be a more accurate measure of wealth than personal income, but such a concept is largely foreign in Thailand where income is reported individually. If Thai incomes are doubled to reflect two-earner households, some of the disparity is erased, but it is very doubtful that any Thai respondent's household income exceeds 80,000 USD. The difference is also explained by Thailand's position as an upper-middle income country as compared to the high-income economies ${ }^{23}$ represented by English respondents.

\section{Opinion Data}

Thai and English responses were similar in part and different in part. Survey question six asked participants to quantify the threat that human trafficking posed to their community, using a SurveyMonkey tool where respondents chose a

23 World Bank, "World Bank Country and Lending Groups" (2018), online: <https://datahelpdesk.worldbank.org/knowledgebase/articles/906519-world-bank-country-andlending-groups $>$ 
number between 0 and 100, where 0 was the lowest threat level and 100 was the highest. Responses were very close: Thai respondents $(\mathrm{M}=29.99, \mathrm{SD}=23.14)$ and English respondents $(\mathrm{M}=32.71, \mathrm{SD}=25.9)$ considered trafficking a low or moderate threat in their communities. The most remarkable difference between groups was that 13 Thai respondents perceived threat levels in the 50-59 range whereas only five English participants reported perceived threat level in the same range. Figure 5 contains a graphical representation of question six data.

Figure 5: Survey question six response frequencies by language

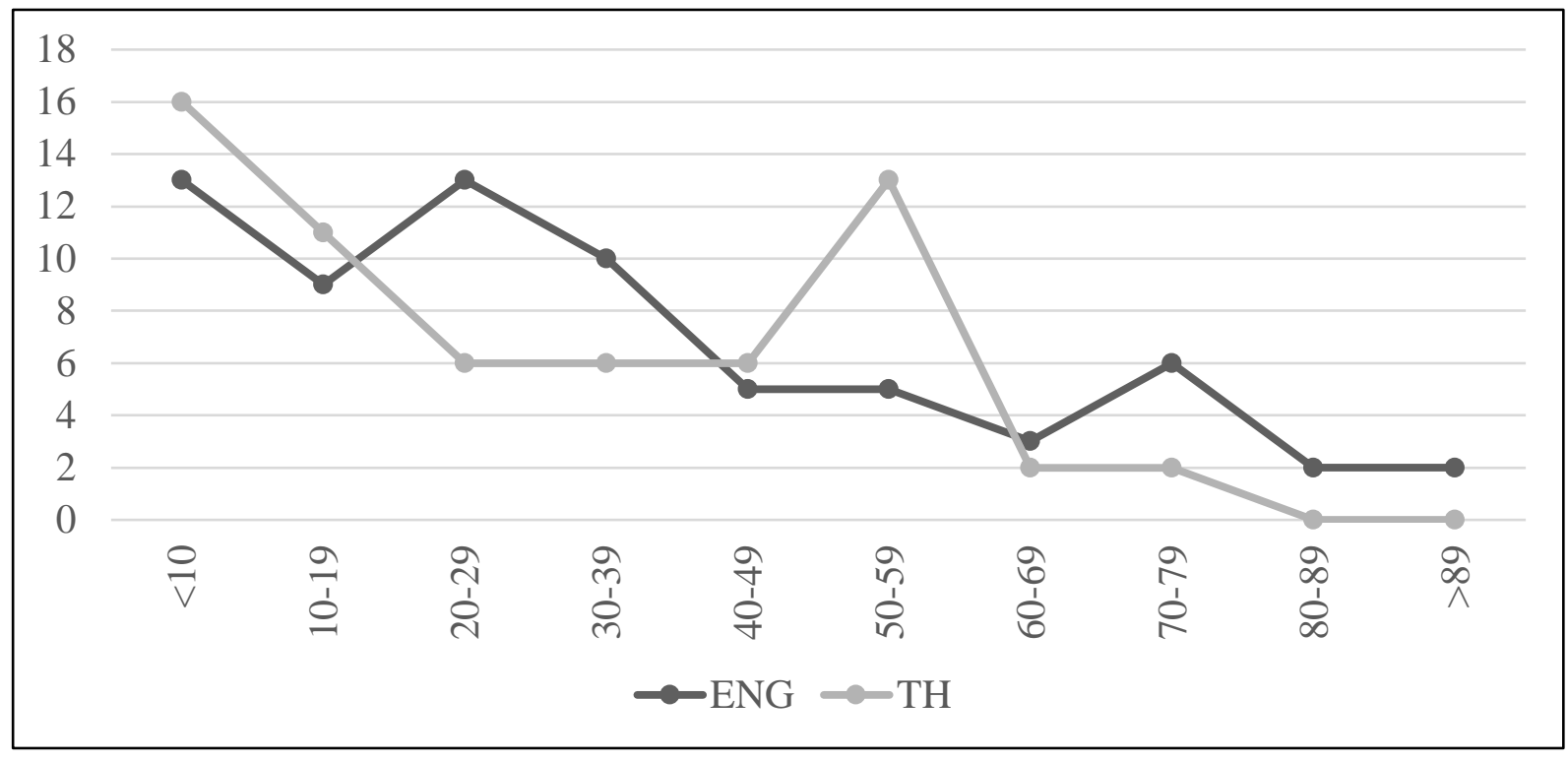

Several trials of one-way ANOVA were run to assess the presence of significant differences between groups with regards to question six. There were no significant differences of opinion between languages, sexes, income groups, or education groups. ANOVA found a statistically significant difference in opinion among age groups $(\mathrm{F}(4,130)=2.711, \mathrm{p}=0.033)$. A Tukey post-hoc test revealed participants aged 60 and older perceived the overall threat of human trafficking $(\mathrm{M}=54.63, \mathrm{SD}=25.35)$ as higher than respondents in both the 30-39 age group $(\mathrm{M}=29.22, \mathrm{SD}=21.92, \mathrm{p}=0.039)$ and $40-49$ age group $(\mathrm{M}=25.50, \mathrm{SD}=25.76$, $\mathrm{p}=0.028)$. However, Kruskal-Wallis and Welch tests failed to verify the presence of significant differences between groups ( $p>0.05)$.

Question seven asked participants to estimate the level of association between human trafficking and several factors. Descriptive statistics showed Thai respondents generally perceived lower association on all factors. A one-way ANOVA found several statistically significant differences between English and Thai language respondents. English language participants $(\mathrm{M}=4.16, \mathrm{SD}=1.09, \mathrm{p}$ $=0.000)$ felt statelessness was more highly associated with trafficking than Thais $(\mathrm{M}=3.20, \mathrm{SD}=1.23, \mathrm{p}=0.000)$. Thai-language respondents $(\mathrm{M}=2.11, \mathrm{SD}=1.09$, $\mathrm{p}=0.043)$ were less likely to think religion was associated with trafficking than 
native speakers of English $(\mathrm{M}=2.49, \mathrm{SD}=1.029, \mathrm{p}=0.043)$. Native speakers of Thai $(\mathrm{M}=3.63, \mathrm{SD}=1.02, \mathrm{p}=0.002)$ were more likely to associate community morals with trafficking than English-language respondents $(\mathrm{M}=3.00, \mathrm{SD}=1.25, \mathrm{p}$ $=0.002)$. Bad parenting was thought to share a higher association by Thais $(\mathrm{M}=$ $3.62, \mathrm{SD}=1.11, \mathrm{p}=0.005)$ as compared to English speakers $(\mathrm{M}=3.04, \mathrm{SD}=1.20$, $\mathrm{p}=0.005)$. Prostitution was more highly associated by English speakers $(\mathrm{M}=4.49$, $\mathrm{SD}=1.03, \mathrm{p}=0.003)$ than by Thais $(\mathrm{M}=3.89, \mathrm{SD}=1.20, \mathrm{p}=0.003)$. Finally, war and violent conflict were thought to be more strongly associated with trafficking by English participants $(\mathrm{M}=4.24, \mathrm{SD}=1.05, \mathrm{p}=0.000)$ than by Thai respondents $(\mathrm{M}=2.52, \mathrm{SD}=1.28, \mathrm{p}=0.000)$. Kruskal-Wallis and Welch tests showed statistically significant differences between the same groups as the ANOVA ( $p<$ $0.05)$.

Table 2: One-way ANOVA, associated factors and language

\begin{tabular}{|c|c|c|c|c|c|c|}
\hline & & Sum of squares & $\mathrm{df}$ & Mean squares & $\mathrm{F}$ & Sig \\
\hline Statelessness & $\begin{array}{l}\text { Between groups } \\
\text { Within groups } \\
\text { Total }\end{array}$ & $\begin{array}{l}31.176 \\
177.660 \\
208.836\end{array}$ & $\begin{array}{l}1 \\
132 \\
133\end{array}$ & $\begin{array}{l}31.176 \\
1.346\end{array}$ & $163^{23 .}$ & .000 \\
\hline Religion & $\begin{array}{l}\text { Between groups } \\
\text { Within groups } \\
\text { Total }\end{array}$ & $\begin{array}{l}4.659 \\
145.220 \\
149.879\end{array}$ & $\begin{array}{l}1 \\
130 \\
131\end{array}$ & $\begin{array}{l}4.659 \\
1.117\end{array}$ & $\begin{array}{ll} & 4.1 \\
71 & \end{array}$ & .043 \\
\hline $\begin{array}{l}\text { Community } \\
\text { morals }\end{array}$ & $\begin{array}{l}\text { Between groups } \\
\text { Within groups } \\
\text { Total }\end{array}$ & $\begin{array}{l}13.222 \\
171.138 \\
184.361\end{array}$ & $\begin{array}{l}1 \\
131 \\
132\end{array}$ & $\begin{array}{l}13.222 \\
1.306\end{array}$ & $121^{10 .}$ & .002 \\
\hline $\begin{array}{l}\text { Bad } \\
\text { parenting }\end{array}$ & $\begin{array}{l}\text { Between groups } \\
\text { Within groups } \\
\text { Total }\end{array}$ & $\begin{array}{l}11.154 \\
176.398 \\
187.552 \\
\end{array}$ & $\begin{array}{l}1 \\
132 \\
133 \\
\end{array}$ & $\begin{array}{l}11.154 \\
1.336\end{array}$ & $47^{8.3}$ & .005 \\
\hline Prostitution & $\begin{array}{l}\text { Between groups } \\
\text { Within groups } \\
\text { Total }\end{array}$ & $\begin{array}{l}11.712 \\
165.243 \\
176.955 \\
\end{array}$ & $\begin{array}{l}1 \\
132 \\
133 \\
\end{array}$ & $\begin{array}{l}11.712 \\
1.252\end{array}$ & $566^{9.3}$ & .003 \\
\hline $\begin{array}{l}\text { War and } \\
\text { violent } \\
\text { conflict }\end{array}$ & $\begin{array}{l}\text { Between groups } \\
\text { Within groups } \\
\text { Total }\end{array}$ & $\begin{array}{l}99.101 \\
180.720 \\
279.821 \\
\end{array}$ & $\begin{array}{l}1 \\
132 \\
133 \\
\end{array}$ & $\begin{array}{l}99.101 \\
1.369\end{array}$ & $384^{72 .}$ & .000 \\
\hline
\end{tabular}


Possible explanations for differences between groups include culture and religion. As a primarily Buddhist eastern culture, Thailand tends to be more collectivist than its primarily Christian, western, English-speaking counterparts ${ }^{24}$. A collectivist culture would more likely hold the group responsible for wellbeing or ills in the community. Thais may also be more likely to hold a positive or neutral view of religion considering the prominent role Buddhism plays in most aspects of life in Thailand; whereas the second most common religious belief in North America and Europe is atheism or no religious affiliation ${ }^{25}$, thereby suggesting pervasive acrimony toward religion among English speakers. Unfortunately, this study could not provide more data on religious or collectivist/individualist beliefs. Figure 6 shows responses on question seven.

Figure 6: Survey question seven regarding association between factors and trafficking.

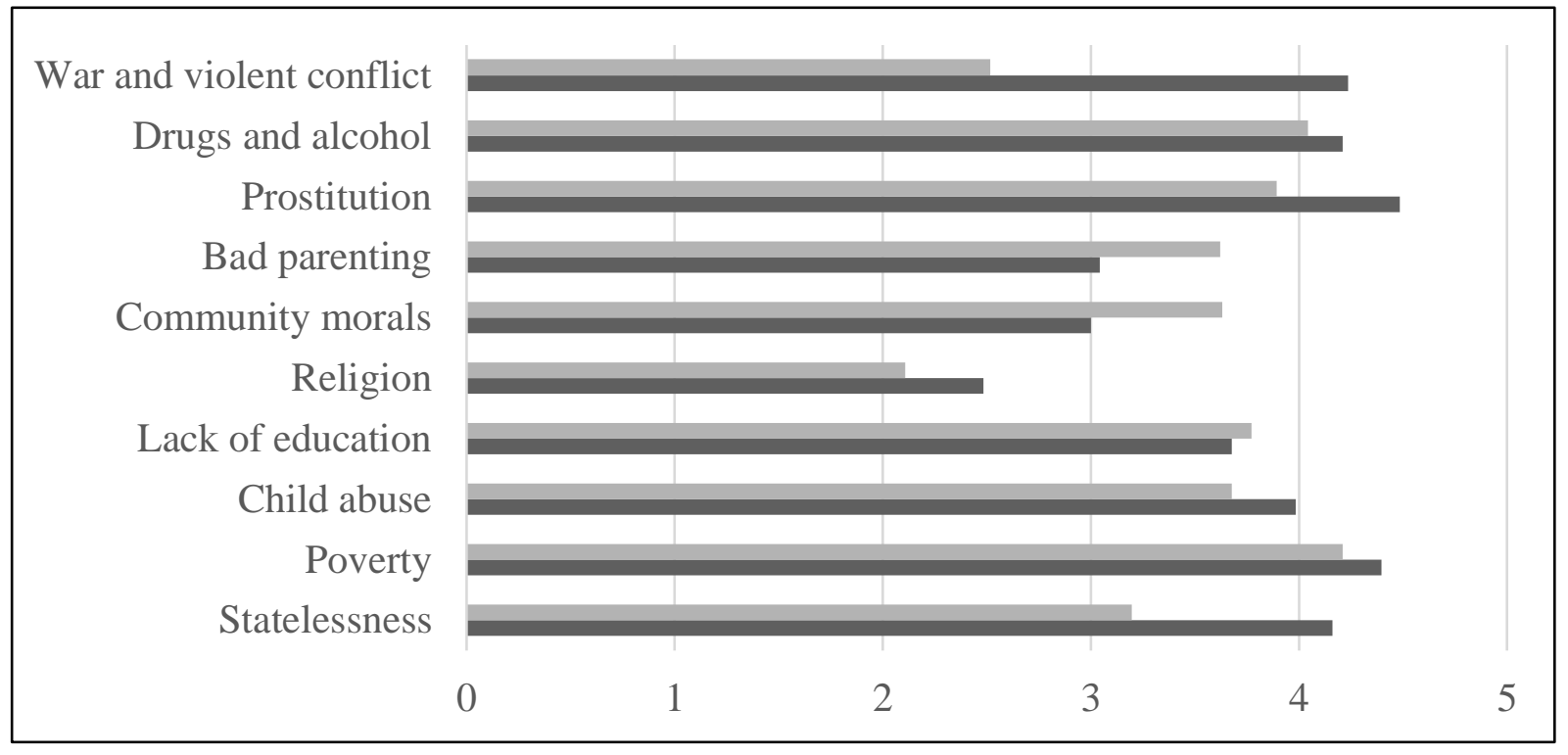

A one-way ANOVA also found statistically significant differences between participants with a high school education as compared to those with a graduate degree, on the relationship between poverty and trafficking $(\mathrm{F}(3,130)=3.972, \mathrm{p}=$ $0.01)$. Respondents with a graduate degree $(\mathrm{M}=4.47, \mathrm{SD}=0.90)$ perceived a very strong association between poverty and trafficking as compared to those with a high school education $(\mathrm{M}=3.25, \mathrm{SD}=1.26)$. A Kruskal-Wallis test confirmed this

24 David Robson, "How East and West Think in Profoundly Different Ways" $B B C$ (19 January 2017), online: The BBC <http://www.bbc.com/future/story/20170118-how-east-and-west-think-inprofoundly-different-ways>; Hofstede Insights, “Country Comparison” (2019), online: <https://www.hofstede-insights.com/country-comparison/>

25 Gabe Bullard, "The World's Newest Major Religion: No Religion" Nat Geo (22 April 2016), online: National Geographic <https://news.nationalgeographic.com/2016/04/160422-atheismagnostic-secular-nones-rising-religion/> 
difference $\left(\mathrm{X}^{2}(1)=8.234, \mathrm{p}=0.041\right)$. A two-way ANOVA was used to assess the possibility that language was an interfering variable due to absence of English participants in the high school education category. Results of the two-way ANOVA showed no significant relationship between language and education $\left(\mathrm{X}^{2}(2,127)=2.841, \mathrm{p}=0.062\right)$, thereby further validating results of the one-way ANOVA.

An additional one-way ANOVA found significant differences between male and female opinions regarding association between community morals and trafficking $(\mathrm{F}(1,131)=4.230, \mathrm{p}=0.042)$. Females $(\mathrm{M}=3.47, \mathrm{SD}=1.04)$ tended to believe community morals shared a higher association with trafficking than males $(\mathrm{M}=3.04, \mathrm{SD}=1.36)$. A Kruskal-Wallis test confirmed this the difference $\left(\mathrm{X}^{2}(1)=\right.$ $4.020, p=0.045)$. In order to assess potential interrelationships between gender and language, a two-way ANOVA was performed whose results showed no significant interaction between language and $\operatorname{sex}(F(1,129)=1.450, p=0.231)$, indicating the disproportionately high number of Thai female respondents did not affect the outcome of the one-way ANOVA.

Question eight asked participants what effect, if any, legalized prostitution would have on human trafficking. On question eight, responses were remarkably different on the basis of language and gender. Figure 7 shows question eight data in bar graphs.

Figure 7: Survey question eight by respondent language.

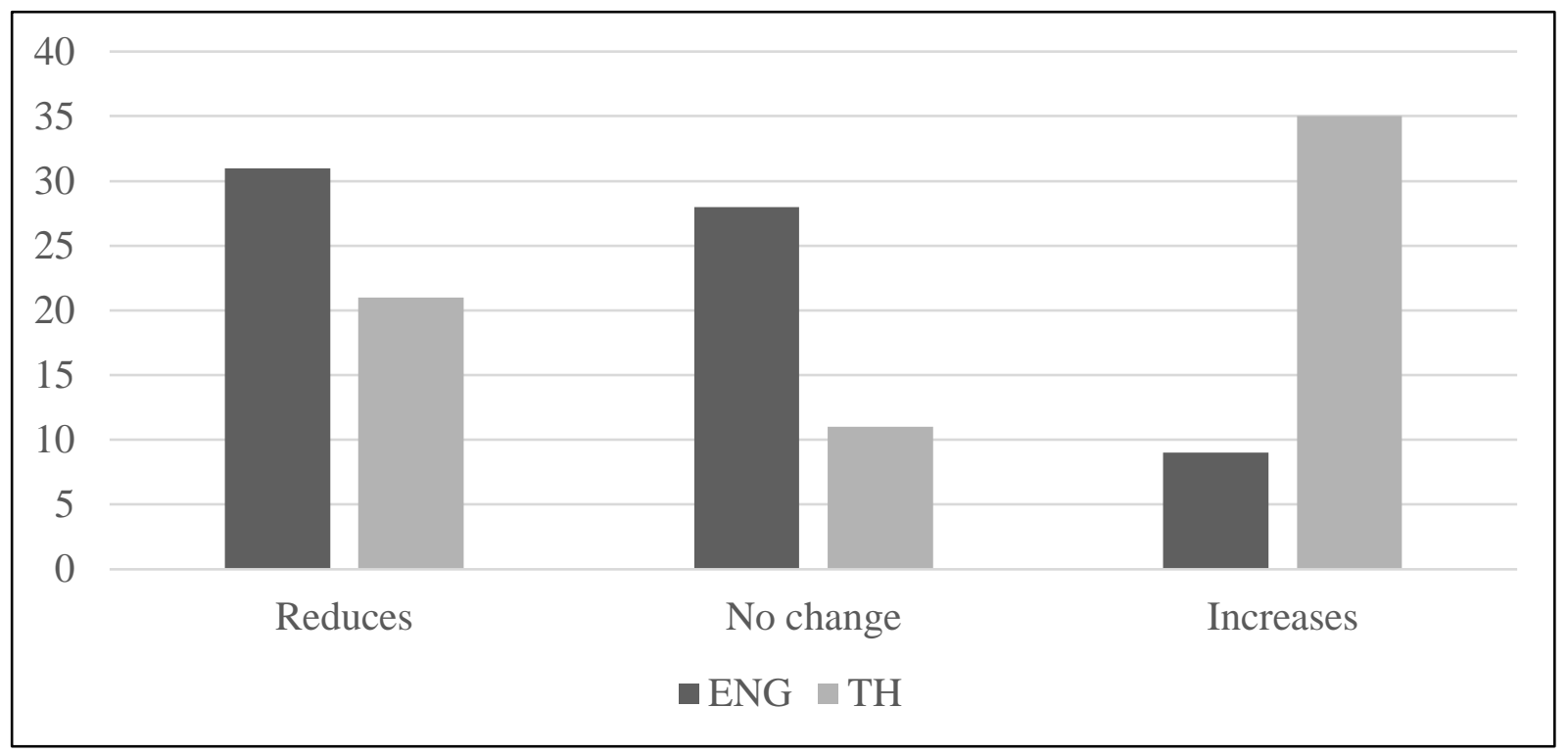

A Chi-Square test showed highly statistically significant association between beliefs regarding potential effects of legalized prostitution and survey language $\left(\mathrm{X}^{2}(2, \mathrm{~N}=135)=24.69, \mathrm{p}<0.005\right)$. Phi and Cramer's $\mathrm{V}$ tests showed very strong relationships between survey language and attitudes toward question eight $(\mathrm{p}<$ 0.0005). English respondents most often believed legalized prostitution would 
decrease trafficking, followed by a null effect, and increased threat, respectively. In contrast, Thai respondents were more polarized with most believing legalization would increase trafficking, followed by decrease, and lastly a null effect.

A Chi-Square test also showed significant association between gender and question eight $(p=0.001)$. The most common response among males was that legalization of prostitution would reduce threat of trafficking, followed by a null effect, and increased threat, respectively. Female responses followed the opposite pattern: they most often felt legalization of prostitution would increase the threat of trafficking, followed by a null effect, and decreased threat, respectively. Figure eight shows overall male and female responses follow opposing trend lines.

Figure 8: Survey question eight by respondent gender

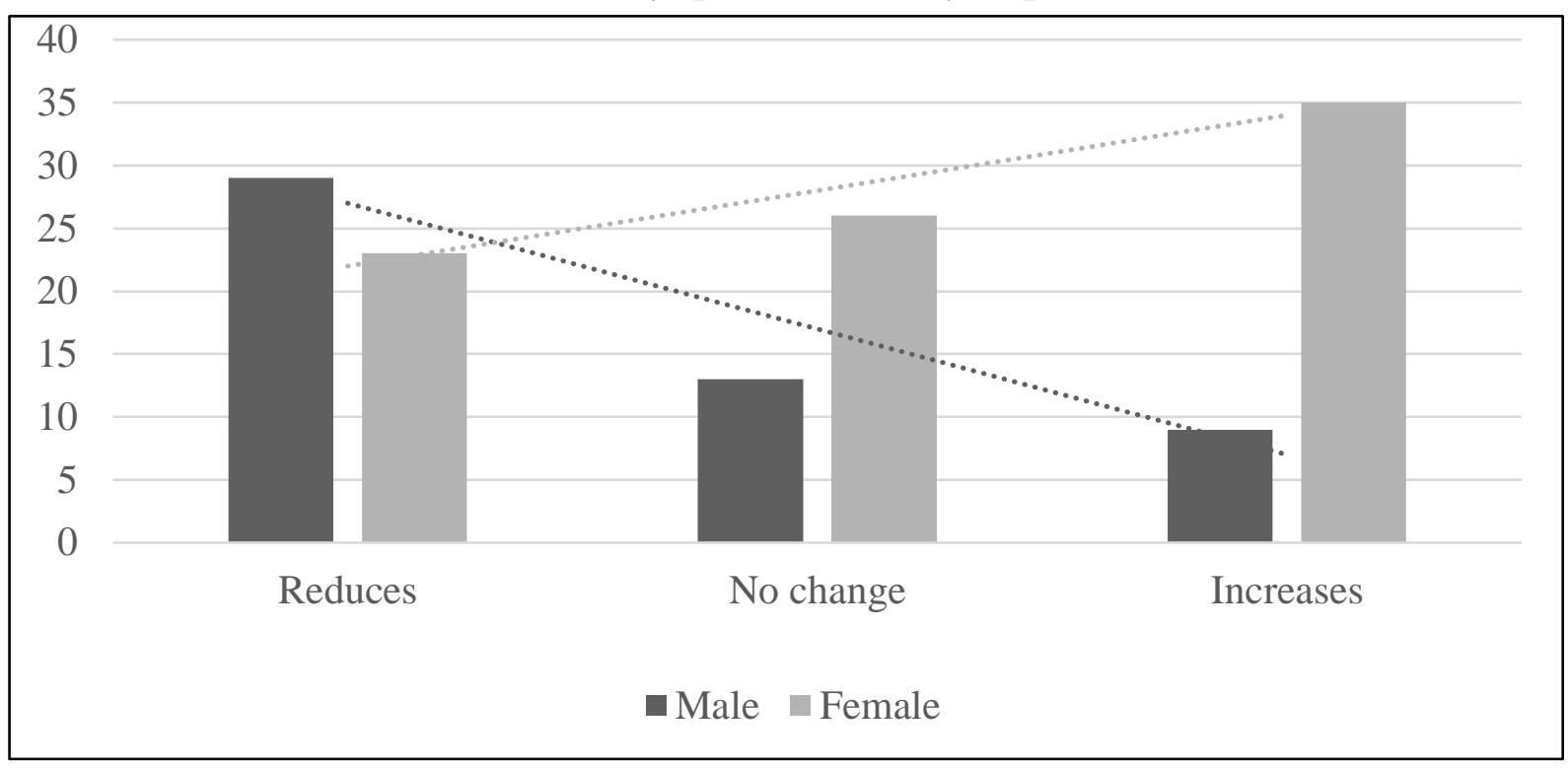

Worthy of note was the likely impact Thai-language female respondents had on data distribution in this question. Among the four respondent groups of English and Thai males and females, only English males followed the overall trends for both their gender and language. Thai female responses reflected the data trend among Thai respondents, but not among female respondents together. Thai and English females strongly disagreed on the issue, with just under 20 percent of English females thinking trafficking threats would increase under legal prostitution versus over 58 percent of Thai females. Moreover, Thai females were more divided on the issue, with the larger two groups reporting at the poles and only 14 percent in the middle compared to 52 percent of English females who responded, "no change." Thai males and females showed similar aversion to the "no change" category. Like Thai females, the most frequent response among Thai males was "increase," but nearly as many responded "decrease." The most decisive group - and the group whose responses were most unlike any other 
group - was English males, of whom just over 6 percent responded "increase" as compared to over 65 percent for "decrease." Figure nine shows distribution of responses separated into language and sex groups.

Figure 9: Survey question eight response frequency by gender and language

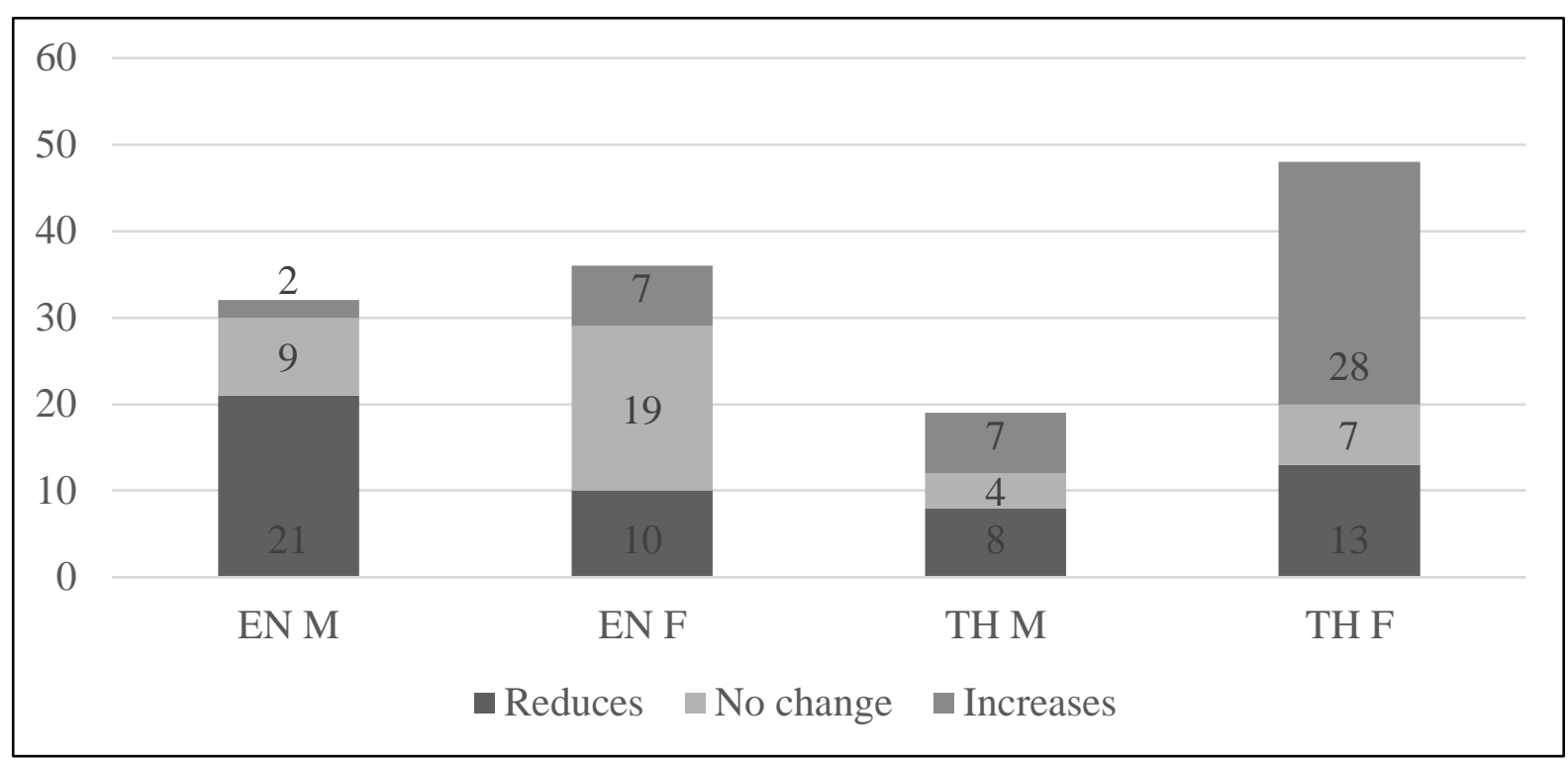

No other significant associations between question eight and participant groupings were discovered.

Question nine asked participants to rank four reasons why people are trafficked, from 1 to 4 where 1 was the most common reason and 4 was the least common reason. Almost one-third of Thai language respondents did not complete this question. The remaining data showed similar attitudes between Thai and English surveys. Both groups believed the most common reason for trafficking was prostitution, followed by labor, household servanthood, and organ harvesting. Table 3 contains the distribution of data where cells are highlighted with darker color to indicate higher numbers of responses. 
Table 3: Survey question nine regarding ranking most common reasons for trafficking.

\begin{tabular}{|ll|l|l|l|l|}
\hline & & 1 st & 2nd & 3rd & 4th \\
\hline Labor & ENG & 10 & 34 & 15 & 9 \\
& TH & 15 & 20 & 6 & 9 \\
\hline Prostitution & ENG & 46 & 12 & 9 & 1 \\
& TH & 29 & 10 & 3 & 5 \\
\hline Household & ENG & 7 & 13 & 33 & 15 \\
servant & TH & 4 & 7 & 24 & 10 \\
\hline Organ & ENG & 5 & 9 & 11 & 43 \\
harvesting & TH & 6 & 11 & 16 & 19 \\
\hline
\end{tabular}

\section{DISCUSSION}

Literature suggests as many as 40 million people are trapped in slavery, indicating they have been victims of human traffickers whose aggregate profits are greater than the entire gross domestic product of more than 100 countries. ${ }^{26}$ Despite these alarmingly high numbers, attitudes regarding the direct threat were fairly cool among participants. On question six, hypothesis 1 was rejected in part as a battery of statistical tests failed to find any reliable difference between groups on the question of how great a threat human trafficking posed. Thai and English respondents ranked forms of trafficking identically on question nine, again rejecting hypothesis 1 in part. Hypothesis 1 was confirmed in part by results on questions seven and eight. Data also showed some difference of opinion among participants on the basis of gender and education, but the most significant and robust differences were found between languages.

Language and culture are inseparable ${ }^{27}$; one influences and is influenced by the other. Thai language respondents, as representatives of a more collectivist culture $^{28}$, were significantly more likely than their English counterparts to believe trafficking is affected by family and community behavior or morals. English respondents may have showed preference for individualism when they perceived higher association of religion with trafficking. A study has found non-religious

26 Data was retrieved using the tool at World Bank, "GDP Ranking" (2018), online: <https://datacatalog.worldbank.org/dataset/gdp-ranking>

27 Wenying Jiang, "The Relationship between Culture and Language", 54:4 ELT J 328-334, online: < http://www.linguisticsnetwork.com/wp-content/uploads/The-relationship-betweenculture-and-language.pdf>; Tengku Mahadi \& Sepideh Jafari, "Language and Culture", 2:17 Int $\mathrm{J}$ of Hum \& $\quad$ Soc Sci $230-235, \quad$ online: <https://www.ijhssnet.com/journals/Vol_2_No_17_September_2012/24.pdf>

28 Hofstede, supra note 24. 
people rate lower on the collectivism scale compared to religious people. ${ }^{29}$ The largest differences between English and Thai respondents were regarding statelessness and war and violent conflict; a complex mix of sociocultural, socioeconomic, educational, institutional, and linguistic factors are likely to explain these findings.

Results from survey question eight regarding legalization of prostitution confirmed hypothesis 2 and illustrated how two distinct cultures perceive the same issue very differently. Thai language respondents tended to believe human trafficking would increase with legal prostitution while English respondents believed the opposite. Additionally, male and female opinions opposed one another. Results reflected classic dichotomies of East and West, male and female.

On the question of "why" groups held different opinions, there are varied possibilities. To some, it may seem intuitive to consider participants' responses as having been affected by their own political perspectives, and that they responded based on their feelings about the morality of prostitution. The Western world, and Europe in particular, tends to be more liberal on questions of morality than the Eastern world. ${ }^{30}$ With this view, we could assume Easterners felt both human trafficking and prostitution were immoral acts, so legalization of a malum in se act was both inappropriate and unlikely to lead to a reduction in another such act. Westerners' political beliefs, in contrast, would tend to lead them to conclude that while human trafficking is malum in se, the act of prostitution itself is but malum in jure, and by relieving the legal pressure on the relatively benign sexual services industry, human trafficking could be reduced via government oversight and regulation. The logic is that the practice of buying and selling sex is historically prevalent, and that supply and demand are sustainable in perpetuity, so the best course is to integrate participants into formal economies where customers and workers can enjoy rights, contribute taxes, and receive protections against violence, exploitation, or disease. The Dutch model, for example, legalizes licensed sex work and criminalizes unlicensed sex work; licenses are not granted to trafficking victims, so traffickers are pushed out of the market due to availability of licensed, legal prostitutes. ${ }^{31}$ In this legalization scenario, governments gain revenues through taxation of sex markets whose participants are no longer marginalized, stigmatized, or left vulnerable to abuse. ${ }^{32}$

29 Taylor Stark, "Does God Matter? Religion in Individualistic and Collectivistic Personalities", (Hillsboro, OR, USA: Graduate School of Professional Psychology, Pacific University, 2009)

30 Pew Research Center, "Global Views on Morality" (2014), online: <http://www.pewglobal.org/2014/04/15/global-morality/table/homosexuality/>

31 Samuel Lee \& Petra Persson, "Human Trafficking and Regulating Prostitution" (2018), online: $<$ https://web.stanford.edu/ perssonp/Prostitution.pdf>

32 Erin Albright \& Kate D'Adamo, "Decreasing Human Trafficking through Sex Work Decriminalization" (Jan 2017) AMA J of Eth, online: <https://journalofethics.amaassn.org/article/decreasing-human-trafficking-through-sex-work-decriminalization/2017-01> 
Theoretically, the legalization argument seems to stand up, but studies suggest it is more fantasy than reality. A study analyzed data from 150 countries and found higher trafficking inflows in countries with legal prostitution. ${ }^{33}$ Researchers have argued that no current systems effectively prevent and suppress trafficking but criminalizing the purchase of sex has greater potential to eradicate trafficking because supply decreases alongside demand. ${ }^{34}$ Thai survey responses may have reflected the conservative Eastern political view that prostitution is illegal because it is inherently immoral and harmful to society, and a change in its legal status would only increase associated immoral and harmful practices such as human trafficking; in this case, that conservative ideal is supported by empirical evidence. Somewhat counterintuitively, English respondents associated prostitution with trafficking more than Thais in question eight and believed legalizing prostitution would decrease trafficking in question eight; this combination of answers is either logically inconsistent, or it suggests English respondents believed the law itself was somehow a cause of trafficking. Proponents of the Dutch model would likely agree that criminalization of prostitution creates more opportunity for traffickers and thereby raises the level of association between trafficking and prostitution in a market where all suppliers are criminals.

Survey results also showed significant differences in opinions between males and females. Male responses tended to reflect English response patterns while the female responses more resembled Thai language responses. Coincidentally, Thai culture exhibits much lower masculinity than Western countries like the United States, United Kingdom, Ireland, France, Germany, and Canada. ${ }^{35}$ Thai culture is also distinctly more feminine than any other country in Asia, according to Hofstede's cultural dimensions. Like language, gender influences beliefs. The survey data reflected another study's discovery that men and liberals support prostitution more than women and conservatives ${ }^{36}$, implying that, on the question of prostitution, females and feminists break from liberal ranks. Therefore, there was more influencing survey data than mere political affiliation.

Feminist philosophers have at numerous occasions commented on how prostitution harms women; how it reinforces pernicious stereotypes of women as the sexual servants of men; how it exploits social vulnerabilities and unreasonably threatens the health and wellbeing of women. ${ }^{37}$ That is not to say there are not

33 Seo-Young Cho, Axel Dreher, \& Eric Neumayer, "Does Legalized Prostitution Increase Human Trafficking?" (2013) 41 J World Dev 67-82, online: <https://www.sciencedirect.com/science/article/pii/S0305750X12001453?via\%3Dihub>

34 Lee \& Persson, supra note 31.

35 Hofstede, supra note 24.

36 Niklas Jakobsson \& Andreas Kotsadam, "Gender Equity and Prostitution: An Investigation of Attitudes in Norway and Sweden" (2011) 17:1 J Fem Econ 31-58, online: <https://www.tandfonline.com/doi/full/10.1080/13545701.2010.541863>

37 Laurie Shrage, "Feminist Perspectives on Sex Markets" (2016) Stanford Encyclopedia of Philosophy, online: <https://plato.stanford.edu/entries/feminist-sex-markets/\#Pros> 
feminists who believe in legalized and regulated prostitution, but it is a myth that more than a minority of radical feminists support legalization as a means toward greater gender equity. ${ }^{38}$ Data from the survey reflected a relative ignorance of feminist philosophy on the part of English males, and a possible reluctance among English females to align with conservative politics, which usually threaten feminist values. English-speaking females, most of whom perceived the legal status of prostitution as having no impact on trafficking, may have also gained exposure to literature regarding the ineffectiveness of any current reduction strategy, which left them feeling ambivalent about effects of law on trafficking.

While cultural perceptions may have significant bearing on how individuals responded to survey questions, there are probably other, more prominent factors influencing governments. Countries around the world have nearly universally adopted anti-trafficking treaties and drafted legislation to criminalize trafficking and exploitation, but literature showed broad international disparities in enforcement, prosecution, and conviction. By the letter of the law, human trafficking is a criminal act virtually everywhere on earth, but the economics of enforcement leave many laws without significant effect. Victims of human trafficking tend to come from impoverished communities, and unfortunately, those communities simply do not have the capital and manpower to prevent and suppress the trade.

Supporters of legalization of prostitution probably recognize that sex trafficking is the most common form, and that if their theory were correct, a change in laws could result in a reduction in aggregate levels of human trafficking by up to half or more. ${ }^{39}$ Nevertheless, it remains unlikely that more than a handful of countries would ever seriously consider legalizing prostitution as moral, ethical, and religious traditions adamantly oppose the practice. Furthermore, robust empirical data has shown trafficking and prostitution are positively correlated. ${ }^{40}$ For more reasons than mere culture, feminism, political ideology, or even economics, prostitution is likely to remain a crime in the vast majority of the world.

Aside from the question of prostitution, participants reported perceptions that numerous other factors relate to trafficking, and unlike the issue of prostitution, the other associated factors cannot be nullified by promulgation, amendment, or repeal of law. Factors such as poverty, child abuse and neglect, lack of access to quality education, statelessness, war, and violent conflict have limited personal freedoms and self-actualization of individuals since time immemorial. Progress has been made on alleviating the strain of these macroenvironmental variables, but there is no indication that such factors shall ever cease to exist.

38 Lara Gerassi, “A Heated Debate: Theoretical Perspectives of Sexual Exploitation and Sex Work” (2016) 42:4 J Sociol Soc Welf 79-100, online: <https://www.ncbi.nlm.nih.gov/pmc/articles/PMC4730391>

39 UNODC, supra note 1.

40 Cho, Dreher, \& Neumayer, supra note 33. 
Regarding research question three on what stakeholders can do to reduce human trafficking, survey respondents made suggestions in question 10 that reflected literature sources. Question ten responses addressed four main ways to combat trafficking. First, governments and NGOs should utilize communication and awareness campaigns to spread the word about what human trafficking is, its related factors, potential at-risk groups, and how to contact law enforcement if individuals see something suspicious. Second, individuals need to interact with police and government agencies to exchange information. "If you see something, say something," one respondent remarked. Third, governments need to have harsh penalties for traffickers, actively investigate cases, enforce the law, prosecute and sentence offenders, and protect victims. Fourth, people need to work toward eliminating the underlying causes of trafficking such as poverty, lack of education, and other factors mentioned in survey question seven. The first three types of recommendations are actionable - people can communicate and interact with police or government agencies that enforce a strict and severe law - but eradicating causal factors is a feat that no mass of people nor ambition can achieve within current social, political, and economic systems.

\section{CONCLUSION}

A bilingual survey was administered to collect opinion data regarding human trafficking, associated factors, and potential remedies to the scourge of the modern-day slave trade. Results showed Thai and English language respondents felt about the same on the overall threat of human trafficking in their communities, and they perceived that threat level as relatively low. Different groups of respondents felt differently about what factors are associated with human trafficking. Thai respondents appeared to support a collectivist worldview as compared to English respondents who tended to support more individualistic values.

Both male/female and English/Thai groups disagreed on the question of whether legalized prostitution would produce a positive, negative, or null effect on human trafficking. Male responses trended away from mainstream feminist ideals which generally oppose prostitution. Thai responses, and especially those of Thai females, tended to reflect feminist philosophy and empirical findings which indicate human trafficking is likely to increase under legal prostitution. English female responses were mainly ambivalent on the legalization question, perhaps due to knowledge of the ineffectiveness of both legalization and criminalization around the world. The legalization question is an impressive finding in the study as it exposed flawed, inconsistent logic, or erroneous thinking among Englishspeaking males who believed prostitution is associated with human trafficking and that legalization of prostitution would result in decreased human trafficking. In other words, English-speaking males believed that there presently exists a positive 
correlation between human trafficking and prostitution, but if the law were changed, that correlation would turn negative.

Language was a stronger predictor of opinions regarding human trafficking than sex, age, education, or income. Results supported the theory that language is a corollary of culture, or vice versa, such that a change in either implies a change in the other. Findings did not produce any panacea; rather, this study explored, discovered, and communicated about concomitant matters relevant to the pursuit of eradication of human trafficking. In its 2009 report on trafficking, UNODC ${ }^{41}$ commented on the need for improved legislation and enforcement, but more importantly, for dialog and communication. Indeed, the process of change requires engagement with the public via awareness campaigns, and a destigmatizing of discussion of human trafficking, prostitution, and related harms.

Human trafficking has existed throughout history, and thus if eradication is our ultimate destination, we are still in the first stages. Government agencies should certainly continue strategizing new, comprehensive and holistic approaches to enforcement and adjudication; yet perhaps the most important action required is extensive communication on the issue. Through continued research and reporting, by working together within and between communities, and by cooperating with and between governments, each individual can add momentum to larger-order transformations of their culture and society. If a genuine solution shall emerge, it will undoubtedly materialize as a consequence of overwhelming concern, of robust discussion, and of exhaustive study of this unwelcome plague.

\section{BIBLIOGRAPHY}

Albright, Erin \& D’Adamo, Kate, "Decreasing Human Trafficking through Sex Work Decriminalization" (Jan 2017) AMA J of Eth, online: <https://journalofethics.ama-assn.org/article/decreasing-human-traffickingthrough-sex-work-decriminalization/2017-01>

Bullard, G. (2016). The world's newest major religion: No religion, online: $<$ https://news.nationalgeographic.com/2016/04/160422-atheism-agnostic-secularnones-rising-religion/>

Cho, Seo-Young, Dreher, Alex, \& Neumayer, Eric, "Does Legalized Prostitution Increase Human Trafficking?" (2013) 41 J World Dev 67-82, online: $<$ https://www.sciencedirect.com/science/article/pii/S0305750X12001453?via\%3D ihub>

41 UNODC, "Global Report on Trafficking in Persons" (Vienna, Austria: UNODC, 2009), online: <http://www.unodc.org/documents/Global_Report_on_TIP.pdf> 
Hofstede Insights, "Country Comparison" (2019), online: <https://www.hofstedeinsights.com/country-comparison/>

ILO, "Profits and Poverty: The Economics of Forced Labor", (Geneva, Switzerland: International Labor Organization, 2014), online: <https://www.ilo.org/wcmsp5/groups/public/_ed_norm/declaration/documents/publication/wcms_243391.pdf>

ILO, "Global Estimates of Modern Slavery: Forced Labor and Forced Marriage" (Geneva, Switzerland: International Labor Office, 2017), online: <https://www.ilo.org/global/publications/books/WCMS_575479/langen/index.htm>

Jakobsson, Niklas \& Kotsadam, Andreas, "Gender Equity and Prostitution: An Investigation of Attitudes in Norway and Sweden" (2011) 17:1 J Fem Econ 31-58, online: <https://www.tandfonline.com/doi/full/10.1080/13545701.2010.541863>

Jiang, Wenying, "The Relationship between Culture and Language", 54:4 ELT J 328-334, online: <http://www.linguisticsnetwork.com/wp-content/uploads/Therelationship-between-culture-and-language.pdf $>$

Kirchner, Stephan \& Frese, Vanessa, "Slavery under the European Convention on Human Rights and the Jus Cogens Prohibition of Human Trafficking" (2015) 27:1 Denning L J 130-145, online: <http://www.ubplj.org/index.php/dlj/article/view/1105/1018>

Krejcie, Robert \& Morgan, Daryle, "Determining Sample Size for Research Activities" (1970) 30 Ed \& Psych Meas 607-610, online: <https:/home.kku.ac.th/sompong/guest_speaker/KrejcieandMorgan_article.p>

Lara Gerassi, "A Heated Debate: Theoretical Perspectives of Sexual Exploitation and Sex Work" (2016) 42:4 J Sociol Soc Welf 79-100, online: <https://www.ncbi.nlm.nih.gov/pmc/articles/PMC4730391/>

League of Nations, Convention to Suppress the Slave Trade and Slavery, 1926, 60 LNTS 253, art 4, online: <https://www.refworld.org/docid/3ae6b36fb.html>

Lee, Samuel \& Persson, Petra, "Human Trafficking and Regulating Prostitution" (2018), online: <https://web.stanford.edu/ perssonp/Prostitution.pdf>

Lund Research, "One-way ANOVA" (2018), online: $<$ https://statistics.laerd.com/statistical-guides/one-way-anova-statistical-guide3.php> 
Mace, Stephanie, "Child trafficking: A case study of the perceptions of child welfare professionals in Colorado", (Fort Collins, CO, USA: Colorado State University School of Education, 2013), online: <https://mountainscholar.org/bitstream/handle/10217/78834/Mace_colostate_00 53A_11615.pdf? sequence $=1 \&$ isAllowed $=\mathrm{y}>$

Mahadi, Tengku \& Jafari, Sepideh, "Language and Culture", 2:17 Int J of Hum \& Soc Sci 230-235, online: <https://www.ijhssnet.com/journals/Vol_2_No_17_September_2012/24.pdf>

National Business Research Institute, "Sample Size Calculator" (2018), online: <https://www.nbrii.com/our-process/sample-size-calculator/>

Perez Solla, Maria, "Slavery and Human Trafficking: International Law and the Role of the World Bank", SP Discussion Paper 0904, 2009, online: <https://siteresources.worldbank.org/SOCIALPROTECTION/Resources/SPDiscussion-papers/Labor-Market-DP/0904.pdf>

Pew Research Center, "Global Views on Morality" (2014), online: <http://www.pewglobal.org/2014/04/15/global-morality/table/homosexuality/>

Robinson, Jill, "Public perceptions of human trafficking in Moldova" (2011) 20:3 Psych Inter., 269-279, online: <https://ac.els-cdn.com/S1132055911700527/1s2.0-S1132055911700527-main.pdf?_tid=c865aa80-d0c1-4946-a03b3a21fcdf108e\&acdnat=1549021744_b0eda250a7718b6c44b2c4aed315a535>

Robson, David, "How East and West Think in Profoundly Different Ways" $B B C$ (19 January 2017), online: The BBC <http://www.bbc.com/future/story/20170118-how-east-and-west-think-inprofoundly-different-ways>

Sharapov, Kiril, "Understanding public knowledge and attitudes towards trafficking in human beings", Research Paper: Part 1, (Budapest, Hungary: Center for Policy Studies, Central European University, 2014), online: $<$ http://astradainternational.org//sidocs/3119-Public-knowledge-and-attitudestowards-thb-2014.pdf $>$

Shrage, Laurie, "Feminist Perspectives on Sex Markets" (2016) Stanford Encyclopedia of Philosophy, online: <https://plato.stanford.edu/entries/feminist-sex-markets/\#Pros>

Stark, Taylor, "Does God Matter? Religion in Individualistic and Collectivistic Personalities", (Hillsboro, OR, USA: Graduate School of Professional Psychology, Pacific University, 2009), online: 
<https://commons.pacificu.edu/cgi/viewcontent.cgi?referer=https://adguard.co $\mathrm{m} /$ referrer.html\&httpsredir $=1 \&$ article $=1201 \&$ context $=$ spp $>$

UN General Assembly, United Nations Convention against Transnational Organized Crime, 2000, A/RES/55/25, online: <https://www.refworld.org/docid/3b00f55b0.html>

UN General Assembly, Universal Declaration of Human Rights, 1948, 217 A(III), online: 〈https://www.refworld.org/docid/3ae6b3712c.html>

UN General Assembly, Protocol to Prevent, Suppress and Punish Trafficking in Persons, Especially Women and Children, Supplementing the United Nations Convention against Transnational Organized Crime, 2000, art 3(a), online: <https://www.refworld.org/docid/4720706c0.html>

United States Department of State, Trafficking in Persons Report 2018, (Washington DC: Department of State, 2018) online: <https://www.state.gov/documents/organization/282798.pdf>

UNODC, "Global Report on Trafficking in Persons" (Vienna, Austria: UNODC, 2009), online: 〈http://www.unodc.org/documents/Global_Report_on_TIP.pdf>

UNODC, "Human Trafficking: Organized Crime and the Multibillion Dollar Sale of People", 2012, online: <http://www.unodc.org/unodc/en/frontpage/2012/July/human-trafficking_organized-crime-and-the-multibillion-dollar-sale-of-people.html>

UNODC (United Nations Office on Drugs and Crime), Global Report on Trafficking in Persons, (Vienna: UNODC, 2016) online: UNODC $<$ https://www.unodc.org/documents/data-andanalysis/glotip/2016_Global_Report_on_Trafficking_in_Persons.pdf>

Withers, Melissa, "Pimp Culture Glorification and Sex Trafficking", online (2017) Psych Today <https://www.psychologytoday.com/us/blog/modern-dayslavery/201704/pimp-culture-glorification-and-sex-trafficking>

World Bank, "World Bank Country and Lending Groups" (2018), online: <https://datahelpdesk.worldbank.org/knowledgebase/articles/906519-worldbank-country-and-lending-groups $>$

World Bank, "GDP Ranking" (2018), online: <https://datacatalog.worldbank.org/dataset/gdp-ranking> 


\section{APPENDIX}

1. Where are you from? (city, state, country) คุณมาจากไหน? (อำเภอ, จังหวัด)

2. Please indicate your sex/gender.

เพศ

Male Female Other

ชาย หญิง อื่นๆ

3. How old are you?

อายุ

Under $20 \quad 20-29 \quad 30-39 \quad 40-49 \quad 50-59 \quad 60+$

4. What is the highest level of education you have attained?

ระดับการศึกษา

high school some college, but no degree

bachelor's degree graduate degree

ต่ำกว่ามัธยมต้น มัธยมปลาย ศึกษาระดับมหาวิทยาลัย

(ไม่จบการศึกษา) ปริญญาตรี ปริญญาโท หรือ ปริญญาเอก

5. What is your annual household income?

รายได้ต่อเดือน

$\begin{array}{lll}\text { less than } \$ 12,000 & \$ 12,000-\$ 20,000 & \$ 20,000-\$ 30,000 \\ \$ 30,000-\$ 45,000 & \$ 45,000-\$ 60,000 & \$ 60,000-\$ 80,000\end{array}$

$\$ 80,000+$

รายได้มากกว่า

ต่ำกว่า 6,000 บาท $\quad 6,000-9,000 \quad 9,001-12,000 \quad 12,001-15,000$

$15,001-20,000 \quad 20,001-30,000 \quad 30,001-50,000 \quad 50,000+$

6. Use the slider to indicate how much of a threat human trafficking poses to your community. 0 is the lowest threat level, 100 is the highest. If you're not sure, just guess.

ปัญหาการค้ามนุษย์ได้คุกคาม

ชุมชนของคุณมากน้อยแค่ไหน? (กดปุ่มสไลด์ตามระดับความคิดเห็น, 0 ระดับต่ำสุด, 100 ระดับสูงสุด) ถ้าไม่มั่นใจระดับไหน คาดเดา

7. Please indicate the level of association with human trafficking you think each of the following factors has. If you think one of the factors creates a higher risk of an individual becoming victim to human trafficking, select a higher number. If you think a factor poses a lower level threat, select a lower number. If you're not sure, just guess.

กรุณาช่วยแสดงความคิดเห็น อะไรเป็นปัจจัยทำให้เกิดการค้ามนุษย์ (ถ้าคุณคิดว่า ปัจจัยไหน ทำให้ตกเป็นเหยื่อของการค้ามนุษย์ เลือกระดับสูงกว่า, ถ้าคุณคิดว่า ปัจจัยไหน ทำให้ตกเป็นเหยื่อน้อยกว่า เลือกระดับต่ำกว่า, ถ้าไม่แน่ใจคาดเดา)

$1=$ no significant relationship $\quad 2$ = low-level relationship

$3=$ moderate relationship $\quad 4=$ somewhat strong relationship

$5=$ very strong relationship 




8. What effect, if any, does legalized prostitution have on human trafficking? If you're sure, just guess.

ถ้าการค้าประเวณีถูกกฎหมาย จะเกิดการเปลี่ยนแปลงอะไร ต่อการค้ามนุษย์ (ถ้าไม่แน่ใจ คาดเดา)

a. Legalizing prostitution reduces the threat of human trafficking (less human trafficking with legal prostitution) ถ้าการค้าประเวณีถูกกฎหมาย ปัญหาการค้ามนุษย์จะน้อยลง

b. The threat of human trafficking is the same whether prostitution is legal or illegal (no effect) ไม่เกิดการเปลี่ยนแปลง

c. Human trafficking is likely to increase if prostitution is legal (greater threat with legal prostitution) ถ้าการค้าประเวณีถูกกฎหมาย ปัญหาการค้ามนุษย์จะสูงกว่า

9. Why are people around the world trafficked? Rank the following. \#1 is the most common reason, \#2 is the second most common reason, \#3 is the third most common reason, \#4 is the least common among those listed. อะไรที่เป็นสาเหตุทำให้เกิดการค้ามนุษย์?

a. labor แรงงาน (โรงงาน, การประมง, เกษตรกรรม, อื่นๆ) 
b. prostitution โสเภณี

c. household servant คนรับใช้ในบ้าน (กักขัง)

d. organ harvesting การค้าอวัยวะมนุษย์ (ตับ, ไต, อื่นๆ)

10. How can people prevent human trafficking? (optional, please provide comment)

เราจะสามารถป้องกันไม่ให้เกิดการค้ามนุษย์ได้อย่างไร? (เขียนแสดงความคิดเห็น) 
Adam Tanielian is an English instructor at Saudi Arabia's King Faisal University and researcher at Thailand's National Institute of Development Administration. He holds B.S. degrees in business and math from Michigan Technological University and Mayville State University, respectively. Adam attended Thailand's Ramkhamhaeng University Institute of International Studies for his master's work in business and doctoral work in international law.

Sangthong Tanielian is a graduate of the business college at Thailand's Rajabhat University in Chiang Mai. She provided considerable assistance with translation of the Thai language survey and responses. 